\begin{tabular}{|c|l|}
\hline Title & $\begin{array}{l}\text { Simulation of nonshivering thermogenesis in cold : assessment of uptake and oxidation of free fatty acids in the } \\
\text { thermogenesis of rats treated chronically with norepinephrine and thy roxine }\end{array}$ \\
\hline Author(s) & Moriya, Kiyoshi; Hiroshige, Tsutomu \\
\hline Citation & ACTA UNIVERSITATIS CA ROLINAE : BIOLOGICA, 1979, 347-348 \\
\hline Issue Date & 1981 \\
\hline Doc URL & http:/hdl.handle.net/2115/32836 \\
\hline Type & article \\
\hline File Information & AUC347.pdf \\
\hline
\end{tabular}

Instructions for use 
ACta Universitatis Carolinae - Biologica 1979: 347-348 9. 1981

Hokkaido University, Sapporo, Japan

\title{
SIMULATION OF NONSHIVERING THERMOGENESIS IN COLD: ASSESSMENT OF UPTAKE AND OXIDATION OF FREE FATTY ACIDS IN THE THERMOGENESIS OF RATS TREATED CHRONICALLY WITH NOREPINEPHRINE AND THYROXINE
}

\author{
KIYOSHI MoRIYA and TsUTOMU Hiroshige
}

\section{INTRODUCTION}

In previous studies we inferred that an enhanced nonshivering thermogenesis (NST) in cold-acclimated animals was explicable by an increase in oxidation of plasma free fatty acids (FFA) rather than its elevated uptake by tissues (MoRIYA et al., 1974, 1977). On the other hand, we showed in agreement with LeBLANC and VILLEMAIRE (1970) that chronic treatment with norepinephrine (NE) and thyroxine $\left(T_{4}\right)$ resulted in a simulation of cold acclimation: an increase in NST and uptake of FFA was demonstrated in response to infusion of NE, a mediator of NST (MoRIYA et al., 1975). In this study the mode of action of NE and $\mathrm{T}_{4}$ in the enhanced utilization of FFA was examined in rats.

\section{METHODS}

Wistar male rats aged from 30 to 45 days old, weighing average $112 \mathrm{~g}$, were divided into following four groups. The first group was warm $\left(22^{\circ} \mathrm{C}\right)$-acclimated controls injected s. c. with olive oil vehicle. The second was injected with NE suspended in olive oil in a daily dose of $70 \mu \mathrm{g} / 100 \mathrm{~g}$ body weight (NE group). In the third $\mathrm{T}_{4}$ was injected in a dose of $5 \mu \mathrm{g} / 100 \mathrm{~g}$ ( $\mathrm{T}_{4}$ group). The fourth was cold-acclimated rats exposed to $5^{\circ} \mathrm{C}$. This treatment continued for 6 weeks. The animals were provided with water and rat chow (Oriental MF) ad libitum. $\mathrm{CO}_{2}$ output was measured as an indicator of thermogenesis and plasma FFA uptake and its oxidation were estimated by a constant intravenous infusion method of ${ }^{14} \mathrm{C}$-palmitate albumin complex under pentobarbital anesthesia $(70 \mathrm{mg} / \mathrm{kg}$ body weight, i. p.). Details were given in a previous report (MoRIYA et al., 1977). The diaphragm from an animal in each group was fixed with neutral paraformaldehyde plus glutaraldehyde solution, followed by post fixation with Millonig's solution. A thin section cut on a ultramicrotome was observed under an electron microscope, and the mitochondria number was counted on muscle fibers chosen at random.

\section{RESULTS}

$\mathrm{CO}_{2}$ output, in response to NE infusion at a rate of $2 \mu \mathrm{g} / \mathrm{min}$ for $20 \mathrm{~min}$, increased from $20 \pm 3 \mu \mathrm{mol} / \mathrm{min} / 100 \mathrm{~g}$ body weight to $72 \pm 6$ in NE group $(\mathrm{n}=12)$, from 
$35 \pm 5$ to $64 \pm 5$ in $T_{4}$ group ( $\mathrm{n}=10$ ), from $31 \pm 4$ to $94 \pm 8$ in cold-acclimated rats $(n=12)$ and from $20 \pm 2$ to $43 \pm 3$ in controls $(n=15)$. The increase, was greater in NE group than in controls and was similar in magnitude to cold-acclimated rats. Initial values in $T_{4}$ group were higher than those in controls, but incremental changes due to NE infusion in both groups did not differ. The plasma FFA uptake by tissues increased in response to NE infusion in all groups, but increases of FFA uptake were similar among these groups. The oxidation rate of plasma FFA also increased in all groups. In NE group it was elevated from $0.14 \pm 0.02$ $\mu \mathrm{Eq} / \mathrm{min} / 100 \mathrm{~g}$ to $2.35 \pm 0.30$, from $0.28 \pm 0.07$ to $2.17 \pm 0.33$ in $\mathrm{T}_{4}$ group, from $0.21 \pm 0.03$ to $2.40 \pm 0.24$ in cold-acclimated rats, and from $0.09 \pm 0.01$ to $0.86 \pm$ \pm 0.10 in controls. The increases in the first three groups were greater than that in the controls. Similar fractions of plasma FFA taken up by tissues were oxidized under basal state in these groups, except a higher value in $\mathrm{T}_{\mathbf{4}}$ group. During NE infusion, the percentage of FFA uptake oxidized was elevated to $32 \%$ in controls, $73 \%$ in NE group, $64 \%$ in $\mathrm{T}_{4}$ group and $51 \%$ in cold-acclimated rats. The increase in $\mathrm{NE}$ and $\mathrm{T}_{4}$ group was greater than that in controls and was similar to that of cold acclimated ones. Since the percentage is considered as a good parameter of heat production due to FFA oxidation, relationship between the percentage and $\mathrm{CO}_{2}$ output was examined. No difference was found among the regression coefficient in the four groups. Numbers of mitochondria which are intracellular site of FFA oxidation and respiration were $114 \pm 10 / \mathrm{mm}^{2}$ in control diaphragm, $172 \pm$ \pm 10 in NE group and $205 \pm 10$ in $\mathrm{T}_{4}$ group.

\section{SUMMARY}

In rats treated chronically with $\mathrm{NE}$ and $\mathrm{T}_{4}$, enhanced NAT with a concomitant increase in the utilization of plasma FFA was observed. This increased utilization of plasma FFA was reflected in a more preferential increase in the oxidation of FFA than in FFA uptake. These biochemical findings are consistent with the morphological findings: an increased mitochondria number in skeletal muscles. Both biochemical and morphological changes of similar nature were found in cold acclimated rats.

\section{REFERENCES}

LeBlanc, J., A. Villemarre, 1970: Thyroxine and noradrenaline on noradrenaline sensitivity, cold resistance and brown fat. Amer. J. Physiol. 218: 1742-1745.

MoRiYA, K., H. MAEKUBO, S. ITOH, 1974: Turnover rate of plasma free fatty acids in cold-acclimated rats. Jap. J. Physiol. 24: 419-431.

Moriya, K., H. Maekubo, K. Honma, S. ITOH, 1975: Effects of norepinephrine and thyroxine on the turnover rate of plasma free fatty acids. Jap. J. Physiol. 25: 733-746.

Moryia, K., H. MAEKubo, T. Hiroshige, 1977: Effects of norepinephrine on uptake and oxidation of plasma free fatty acids in cold-acclimated rats. Jap. J. Physiol. 27: 601-616. 